\section{GONDOLATOK A PEPP-RŐL BIZTOSÍTÓI FÓKUSSZAL}

Lencsés Katalin (MABISZ)

\section{ÖSSZEFOGLALÓ}

Az Európai Bizottság 2017 júliusában egy új jogszabálytervezetet nyújtott be, melynek célja egy olyan új egyéni, európai nyugdítermék (PEPP) létrehozása, mely a szándékok szerint növeli a hosszú távú befektetéseket, jobb terméket kínál a fogyasztók számára, és ösztönzi a határon átnyúló szolgáltatásokat.

Az európai biztosítási szakmának régi hagyományai vannak a hosszú távú befektetések kínálatában, ezen túlmenően jelenleg az egyéni nyugdijtermékek értékesítésében is piacvezetők a biztosítótársaságok. Ebben a pozíciójában az európai biztosítási szakma is szeretne hozzájárulni észrevételeivel az új terméktípus szabályozásának véglegezéséhez. Jelen cikk az Insurance Europe kapcsolódó hivatalos álláspontját mutatja be. Ez a szervezet az európai biztosítók és viszontbiztosítók szövetsége, melynek tagjai a nemzeti szövetségek, amelyeken keresztül az Insurance Europe az európai biztosítási dijbevétel mintegy 95 százalékát képviseli.

\section{SUMMARY}

In July 2017 the European Commission published a draft Regulation for a Pan-European Personal Pension Product (PEPP) that aims at raising more capital for long-term investment, offering enhanced product features for consumer and encouraging cross border provision.

The European insurance industry have a long standing tradition as providers of long term saving products and for the time being the insurance sector is the market leader in the provision on private pension product. In this position the European insurance industry would like to contribute with its comments to the development of this new type of product. Present article summarize the official position of Insurance Europe that is the European insurance and reinsurance federation. Through its 35 member bodies - the national insurance association - it represents insurance and reinsurance undertakings that account for around $95 \%$ of total European premium income.

Kulcsszavak: biztosítás, nyugdíjbiztosítás, PEPP

Keywords: insurance, pension product, PEPP

\section{JEL: E21, E22, G22}

DOI: $10.18530 /$ BK.2018.3.12

http://dx.doi.org/1018530/BK.2018.3.12
Mostanra már hozzászoktunk, hogy az Európai Unió jogalkotási folyamatai kapcsán betűszavakat kell megtanulnunk. Ilyen volt a PRIIPs, IDD, MiFID, és lehetne még tovább sorolni. Jelenleg aktuális feladat, hogy barátkozzunk a PEPP betűszóval, amely szintén egy készülő uniós jogszabályt jelent. Az Európai Bizottság 2017 júniusában benyújtott egy jogszabálytervezetet ${ }^{1}$, melynek célja olyan határon átnyúló, egyéni nyugdíjtermék létrehozása, amely egyszerủ és vonzó, hosszú távú megtakarítási formát kínál az európai állampolgároknak (PEPP - Pan European Personal Pension Product).

Az új európai nyugdíjtermékben lévő potenciál, piacalakító hatás egyelőre nehezen megbecsülhető, ugyanakkor a biztosítóknak mint a jelenlegi legnagyobb piaci szereplőknek az egyéni nyugdíj-megtakarítások területén, oda kell figyelniük a fejleményekre, ha nem szeretnék veszélyben látni a pozíciójukat.

Az induló szövegtervezet jelenleg a szokásos egyeztetési útját járja a Parlamentben és a Tanácsban, a végleges jogszabályi szöveg tehát egyelőre még nem ismert. A bizottsági szövegjavaslat bemutatását az előző cikk (Falco R. Valkenburg) tartalmazza, jelen írás tehát erre nem tér ki. Célunk ugyanakkor megismertetni az olvasóval, hogy mit remél az európai jogalkotó a PEPP szabályozástól, illetve melyek azok a kérdések, melyeket a biztosítási piac szükségesnek tart kiemelni egy nyugdíjcélú termék kapcsán. A biztosítói álláspont bemutatása a biztosítók európai szövetsége, az Insurance Europe hivatalos álláspontjának a bemutatásával történik.

\section{Milyen problémákra keres választ a PEPP?}

Az új jogszabálytervezetet aligha lehet megérteni anélkül, hogy szélesebb európai kontextusba ne helyeznénk.

- Demográfiai folyamatok

A demográfiai folyamatok jól ismertek: az EU28 vonatkozásában² a termékenységi ráta az 1960-as 2,5 átlagról 2016-ra 1,6-ra esett , ezzel párhuzamosan egy most megszülető EU-állampolgár várható életkilátásai átlagosan 10 évvel hosszabbak, mint 1960-ban. Az aktív korú lakosság (15-64 év között) aránya folyamatosan szűkül, miközben a 80 év feletti lakosság aránya a számítások szerint 2050-re megduplázódik, és eléri a 11,4 százalékot. Míg 2006-ban 4 aktív lakos jutott egy inaktívra, addig 2050-re ez az arány 2:1-re fog módosulni a várakozások szerint. ${ }^{4}$ A felosztó-kirovó nyugdíjrendszereket érő kihívások ennek megfelelően széles körben ismertek.

- Jellemzöen alacsony egyéni nyugdij-megtakaritások

Egyéni nyugdíj-megtakarítások esetében olyan termékekről beszélünk, ahol a fogyasztónak (többé-kevésbé) magától kell arra az elhatározásra jutnia, hogy hosszú távú elkötelezettséget vállal egy olyan - jellemzően illikvid - termék mellett, melynek hozadékát a nyugdíjas éveiben 
fogja majd élvezni. Az ilyen típusú döntések nehézkes voltát mutatja az az adat, hogy az EU 25 és 59 év közötti életkor sávba eső népességének mindössze 27 százaléka költ egyéni nyugdijtermékre, ami a teljes népesség 13 százalékát jelenti. ${ }^{5} \mathrm{Az}$ önkéntes nyugdíjcélú megtakarítások összefüggésben az eltérő társadalombiztosítási rendszerek sajátosságaival - lényegében néhány tagországban koncentrálódnak (lásd 1. sz. táblázat), ráadásul az egyes országok megtakarítási megoldásai rendkívül különbözőek, ami megnehezíti az EU-szintű megoldások kialakítását. Az EU-felmérések szerint a jelenlegi privát nyugdíjtermékeknek több hiányosságuk is van, ilyen például a tájékoztatás problémája ${ }^{6}$, a tényleges értékesítési csatornák szűkössége, a rossz ár-érték arány $^{7}$, a szolgáltatóváltás lehetőségének hiánya. Több esetben kritikaként fogalmazódik meg az is, hogy nem biztosított ezen megtakarítások hosszú távú védelme (lásd tőkegarancia elvárása).

1. sz. táblázat: EU-háztartások pénzügyi eszköze, azon belïl készpénz/bankbetétés egyéni nyugdíjtermékek (2015. decemberi adatok)

\begin{tabular}{|l|c|c|c|}
\hline Tagország & $\begin{array}{c}\text { Összes pénzügyi } \\
\text { eszköz (GDP \%) }\end{array}$ & $\begin{array}{c}\text { Készpénz és } \\
\text { bankbetét az összes } \\
\text { pénzügyi eszköz } \\
\% \text {-ában }\end{array}$ & $\begin{array}{c}\text { Egyéni nyugdíj- } \\
\text { termékek aránya } \\
\text { az összes pénzügyi } \\
\text { eszköz \%-ában }\end{array}$ \\
\hline Hollandia & $325 \%$ & $19 \%$ & $0,4 \%$ \\
\hline Egyesült Királyság & $324 \%$ & $24 \%$ & $\mathrm{n} / \mathrm{a}$ \\
\hline Belgium & $309 \%$ & $29 \%$ & $3,4 \%$ \\
\hline Dánia & $294 \%$ & $17 \%$ & $9,9 \%$ \\
\hline Svédország & $281 \%$ & $14 \%$ & $0,9 \%$ \\
\hline Ciprus & $259 \%$ & $63 \%$ & $\mathrm{n} / \mathrm{a}$ \\
\hline Málta & $257 \%$ & $46 \%$ & $9,0 \%$ \\
\hline Olaszország & $251 \%$ & $31 \%$ & $0,9 \%$ \\
\hline Franciaország & $222 \%$ & $28 \%$ & $1,0 \%$ \\
\hline Portugália & $212 \%$ & $44 \%$ & $0,6 \%$ \\
\hline Spanyolország & $187 \%$ & $42 \%$ & $4,2 \%$ \\
\hline Ausztria & $182 \%$ & $41 \%$ & $1,3 \%$ \\
\hline Németország & $182 \%$ & $39 \%$ & $3,9 \%$ \\
\hline Görögország & $148 \%$ & $66 \%$ & $\mathrm{n} / \mathrm{a}$ \\
\hline Finnország & $144 \%$ & $30 \%$ & $4,0 \%$ \\
\hline Luxemburg & $140 \%$ & $50 \%$ & $\mathrm{n} / \mathrm{a}$ \\
\hline Írország & $139 \%$ & $37 \%$ & $1,3 \%$ \\
\hline Bulgária & $135 \%$ & $38 \%$ & $0,3 \%$ \\
\hline Magyarország & $124 \%$ & $28 \%$ & $2,6 \%$ \\
\hline
\end{tabular}

\begin{tabular}{|l|c|c|c|}
\hline Horvátország & $121 \%$ & $55 \%$ & $0,7 \%$ \\
\hline Észtország & $113 \%$ & $29 \%$ & $1,5 \%$ \\
\hline Cseh Köztársaság & $110 \%$ & $52 \%$ & $6,2 \%$ \\
\hline Lettország & $108 \%$ & $34 \%$ & $1,1 \%$ \\
\hline Szlovénia & $102 \%$ & $50 \%$ & $4,8 \%$ \\
\hline Lengyelország & $97 \%$ & $48 \%$ & $0,2 \%$ \\
\hline Litvánia & $92 \%$ & $36 \%$ & $0,1 \%$ \\
\hline Szlovákia & $77 \%$ & $62 \%$ & $2,4 \%$ \\
\hline Románia & $72 \%$ & $35 \%$ & $0,2 \%$ \\
\hline Összesen & $\mathbf{2 2 8} \%$ & $\mathbf{3 0 \%}$ & $\mathbf{2 , 3} \%$ \\
\hline
\end{tabular}

Forrás: Eurostat, European Commission

- Fejletlen tókepiacok a nyugdij-megtakaritások vonatkozásában

Más, fejlett régiókkal összehasonlítva az európai megtakarítások tőkepiaci kitettsége alacsony. Az európai háztartások jellemzően még mindig a bankbetétet részesítik előnyben (lásd 1. sz. táblázat), és a nyugdíjalapok tőkepiaci jelenléte is alacsonyabb, mint más fejlett régiókban (lásd 2. sz. táblázat). Ugyanakkor az európai nyugdíjalapok, illetve a nyugdíj-megtakarításokat kezelő intézményi befektetők jelentős mértékben hozzájárulhatnának az európai részvénypiacok kapitalizációjához. Nem véletlen tehát, hogy a PEPP projekt szorosan kapcsolódik az EU egy másik fontos projektjéhez, a Tőkepiaci Unióhoz (Capital Market Union) ${ }^{8}$, melynek célja a finanszírozási források mozgósítása az európai növekedés érdekében. Ennek része többek között az innovatív megoldások támogatása, a cégek tőkepiaci aktivitásának megkönnyítése, a hosszú távú és fenntartható befektetések ösztönzése, a banki és tőkepiaci kapacitások megerősítése, valamint a határon átnyúló befektetések elősegítése.

2. sz. táblázat: Nyugdíjalapok ${ }^{9}$ tőkepiaci jelenléte (2015. évi adatok)

\begin{tabular}{|l|c|}
\hline Ország & $\begin{array}{c}\text { A nyugdíjalapok által kezelt } \\
\text { vagyon tőkepiaci befektetés } \\
\text { része a GDP \%-ában }\end{array}$ \\
\hline USA & $79 \%$ \\
\hline EU27 (Ciprus nélkül) & $31 \%$ \\
\hline Japán & $30 \%$ \\
\hline Kanada & $77 \%$ \\
\hline Svájc & $118 \%$ \\
\hline
\end{tabular}

Forrás: Európai Bizottság 
- Politikai megfontolások

Természetesen nem hagyható ki a felsorolásból a politikai környezet sem. Nehéz lenne tagadni, hogy az EU több szempontból is válságos időszakot él át mostanában. Ez az EU-testületeket, elsősorban pedig a Bizottságot arra ösztönzi, hogy fokozott aktivitással vesse bele magát Unió-szintű projektekbe, ezzel is bizonyítva azt, hogy a közösség igenis életképes.

Sokan sokszor vádolták már az EU döntéshozóit túlzott bürokratizmussal, a jogalkotási folyamatok elhúzódásával. Nos, a PEPP esetében ez a vád nem áll meg, mivel a jogalkotás a megszokotthoz képest kivételes gyorsasággal történik (ami jelen esetben nem feltétlenül tekinthetö pozitív fejleménynek). Az IDD esetében több mint 4 év telt el a jogszabálytervezet benyújtása és annak véglegezése között. A PEPP esetében ez az időszak minden bizonnyal lényegesen rövidebb lesz. A Bizottság eltökéltségét mutatja az is, hogy a jogszabálytervezet formája rendelet, ami kihirdetéskor hatályossá válik, és nem igényel tagállami implementációt.

\section{Mi lehet a PEPP hozzáadott értéke EU-szinten?}

A jogalkotó várakozásai az előző pontban felsorolt problémákhoz kapcsolódnak, miszerint az új terméktípus segít azokra megtalálni a válaszokat.

- Makroszinten remélt hatás, hogy az egyéni megtakarítások nagyobb arányban kerülnek átcsoportosításra a bankbetétekből a tökepiacok irányába, ezáltal a lakosság nagyobb arányban finanszírozhatja a beruházásokat.

- $\quad$ Egy egyszerű, biztonságos és nagyrészt standardizált termék megjelenése kiegészíti a nemzeti piacokon már meglévő nyugdíjtermékeket, és egyben ösztönzi a nyugdíjcélú megtakarítások növekedését.

- Több tagországban még fejletlen a második, illetve harmadik nyugdíjpillér, ezekben z országokban a PEPP ezt a hiányt is pótolhatná.

- Jelenleg nincs egységes, „harmadik pillér” piac, ami megakadályozza azt, hogy az európai polgár maximalizálja a méretgazdaságosságból, kockázatmegosztásból és innovációból fakadó előnyöket.

- Jelenleg az egyéni nyugdíjtermékek több mint 80 százalékát biztosítók értékesítik (lásd 1. sz ábra). Nem titkolt cél ezen is változtatni, és az értékesítési csatornákat differenciáltabbá tenni.
1. sz. ábra: Egyéni nyugdijtermékek vagyonmegoszlása szolgáltatónként ${ }^{10}$ az Európai Gazdasági Térségben, 2014. év végi adatok szerint ${ }^{11}$

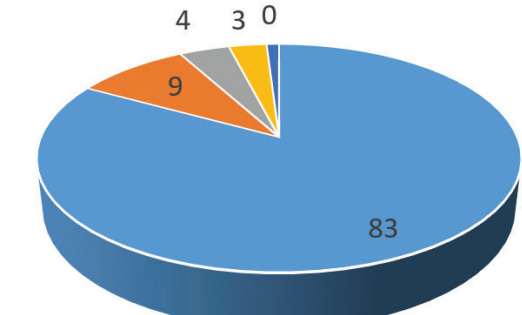

$$
\begin{array}{ll}
\text { - Biztosítók } & \text { - IORP } \\
\text { - Bankok } & \text { - Nyugdíjbiztosítók }
\end{array}
$$

Forrás: EIOPA

\section{Hogyan látja a biztosítási szakma a PEPP tervezetet?}

A jogalkotó várakozásai a PEPP kapcsán tehát jelentékenyek. Kérdés, hogyan látja mindezt a jelenlegi legnagyobb egyéni nyugdijterméket forgalmazó iparág, a biztosítási szakma. Az európai biztosítók témával kapcsolatos álláspontját az európai szövetség, az Insurance Europe anyaga foglalja össze, melyet ez a fejezet mutat be. ${ }^{12}$

Az európai biztosítási szakma természetesen támogat minden olyan kezdeményezést, amely felpörgetheti az egyéni nyugdíjcélú megtakarításokat. Ugyanakkor figyelembevételre ajánl néhány olyan szempontot, melyet egy nyugdítermék kapcsán fontosnak lát, és amely kérdéseket a Bizottság induló szövege nem rendez megnyugtató módon.

1. A valódi nyugdijterméknek a termék tőkegyüjtési és kifizetési szakaszának kihivásaira egyaránt reagálnia kell.

A tervezet jelenleg a tőkegyüjtési szakaszra koncentrál, a kifizetési szakaszra nem fordít elégséges figyelmet, holott éppen ez utóbbi különbözteti meg a nyugdijterméket az átlagos befektetési terméktől (lásd 2. sz. ábra). Az induló szöveg a kifizetési szakasz kapcsán az elvárásokat rugalmasan hagyja, mindössze négy kifizetési lehetőséget sorol fel (járadék, egyösszegű kifizetés, lehívás ${ }^{13}$ vagy ezek valamilyen kombinációja), és azt várja el, hogy legalább az egyikre lehetőség legyen.

Mivel a nyugdíjtermék definiált célja az, hogy időskorban jövedelemkiegészítést nyújtson, a biztosítók álláspontja szerint indokolt, hogy az életjáradékban történő kifizetés a szabályozásban preferenciát kapjon, mivel csak ez ad esélyt az élettartam-kockázat kezelésére. Ezen kockázat alatt azt értjük, hogy az idős ember túl hamar feléli a nyugdíj-megtakarításait, így élete utolsó 
szakaszában megfelelő anyagi eszközök nélkül marad, aminek nemcsak egyéni, hanem társadalmi, szociális vetülete is van. A nyugdíjtermékre úgy szokás tekinteni, mint amelynek az a feladata, hogy nyugdíjba vonuláskor egy adott összeg rendelkezésre álljon, miközben a terméknek legalább annyira feladata lenne, hogy védelmet nyújtson az élettartam-kockázatra is, vagyis a szabályozás vegye figyelembe azt, hogy az átlagos EU-polgár egyre hosszabb ideig él, többnyire túlszárnyalva az aktuáriusok által előzetesen becsült várható élettartamot is.

2. sz. ábra: Milyen a valódi nyugdíjtermék?

$$
\text { Nyugdíjba vonulás }
$$

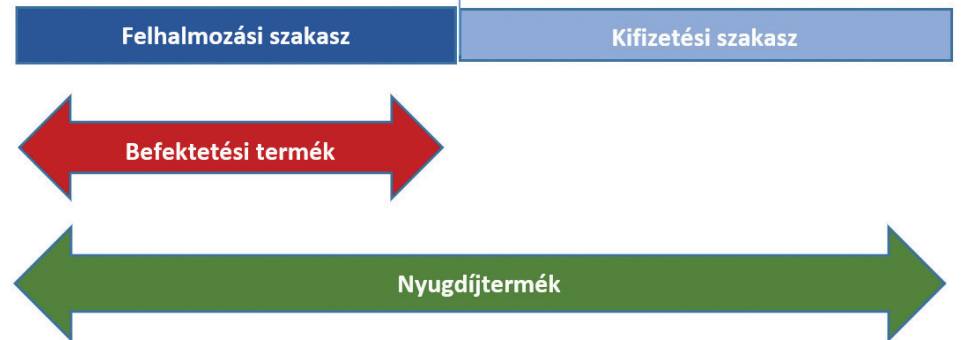

Forrás: Insurance Europe

További problémás eleme a kifizetési szakasznak a szolgáltatóváltás lehetősége, melynek gyakorlati problémáit életjáradékban történő szolgáltatás esetén nem szükséges egy biztosítói szaklapban külön megmagyarázni.

A szakma arra is felhívja a figyelmet, hogy a biztosítási fedezet fontosságát alulértékeli a tervezet, amennyiben azt csak opcióként, mégpedig a befektetői biztonság részeként veszi figyelembe, mivel bizonyos esetekben (pl. munkaképesség elvesztése) meghatározó fontosságú lehet.

\section{Az egyéni megtakaritások biztonságának prioritást kell adni}

A PEPP termék befektetési szabályai közé tartozik, hogy általánosságban tartózkodni kell a kiemelten magas kockázatú eszközöktől. Ezen túlmenően a maximum öt befektetési opció között lennie kell egy alapértelmezett (default) opciónak is, ami legalább tőkegaranciát biztosít. A szöveg ugyanakkor egyenértékűnek tartja a hosszú távú megtakarításokra is kihegyezett - és éppen ezért drága, és így a nyugdíjbefektetés hozamát is terhelő - intézményi garanciát (lásd SII) azzal, amikor a garancia befektetési technikákkal valósul meg (tőkevédelem).

A biztosítói álláspont szerint a fogyasztóvédelem azt kívánja meg, hogy a két megoldás ne legyen egyenértékü, különösen azt figyelembe véve, hogy a rendelettervezet a szolgáltatók széles köre számára teszi lehetővé az európai nyugdíjtermék forgalmazását, mely szolgáltatók szabályozása jelentős eltéréseket mutat. Csak akkor beszélhetünk megfelelő fogyasztóvédelemről, ha az európai fogyasztó ugyanazt a szintű védelmet kapja minden PEPP terméktől, bármely szolgáltatótól is vásárolja meg.

\section{Csak akkor beszélhetünk megfelelő fogyasztóvédelemről, ha az európai fogyasztó ugyanazt a szintú védelmet kapja minden PEPP terméktől.}

A Bizottság által benyújtott induló tervezet szerint a PEPP termék deafult opciójának tartalmaznia kellene az inflációkövetés mechanizmusát is. Az Insurance Europe ezzel kapcsolatban arra hívja fel a figyelmet, hogy az az elvárás, amely a tőkevédelmen túlmenően az inflációkövetésre is kiterjed, lényegében teljesíthetetlen kihívást jelent, tekintve az infláció változékony jellegét, aminek garanciaigénye, illetve annak költsége - különösen hosszú távon - nem prognosztizálható elöre.

3. A PEPP-nek valóban hosszú távú terméknek kell lennie.

Az induló szöveg ötévente lehetővé teszi a szolgáltatóváltást. Ennek racionalitása bizonyos szempontból érthető, ugyanakkor komoly kihívás elé állítja az intézményi befektetőket, mivel megnehezíti, hogy a szolgáltató valóban hosszú távú eszközökben helyezze el a pénzt. Mindezt tovább bonyolítja, hogy az első váltás bármikor megtörténhet, az ötévenkénti korlátozás csak ezt követően lép életbe. A szolgáltatóváltás lehetősége korlátozza a hagyományos biztosítási technikák alkalmazását, úgymint a kockázatmegosztás, illetve pool-technika alkalmazása hozamkiegyenlítésre (adott időszak kiemelkedő hozamának részleges átcsoportosítása későbbi negatív hozamú időszakokra). A túlságosan gyakori váltás lehetősége továbbá azt is megnehezíti, hogy a kisbefektető profitáljon az illikvid eszközosztályok hosszabb távon realizálható hozamaiból.

A probléma áthidalására az Insurance Europe az alábbi javaslatokat teszi.

- Szükséges megtalálni a PEPP rugalmasságának azt a mértékét, ami még lehetővé teszi a szolgáltató számára, hogy az ügyfélbefizetéseket hosszú távon tudja menedzselni.

- Az alapértelmezett (default) befektetési lehetőségnél a tőkegarancia elvárását a lejárati szolgáltatásra kell értelmezni, és nem a lehetséges korábbi váltásra, mivel ez utóbbi rendkívül drágává, illetőleg a befektetést a lejárati időpontig megtartó ügyfelek számára kedvezőtlenebbé tenné a terméket. A jogszabálytervezet szerint elvárt - bármely időpontban érvényesíthető - garancia ára, hogy a korai kiszállás lehetősége miatt csökken annak a valószínűsége, hogy az ügyfél többet kap az előre garantált értéknél, vagyis minimális lesz a garantált tőkeérték feletti hozam.

- Szükséges részletekbe menően rögzíteni a szolgáltatóváltás technikai feltételeit. Ilyen az, hogy az átadott eszközöket tényleges napi értéken kell figyelembe venni. 
Azokban az esetekben, amikor a szolgáltató kollektív befektetési technikákat alkalmaz, rögzíteni kell az egyéni számla elkülönítésének a módszertanát, biztosítva ezzel azt, hogy az átadott eszközök nem haladják meg a kivett kötelezettségeket.

- Végül, de nem utolsósorban a PEPP termék mögött megfelelő prudenciális szabályozásnak kell állnia, a mi tükrözi a szolgáltató hosszú távú kötelezettségvállalását. A Szolvencia II kifejezetten azt biztosítja, hogy megvalósuljon a nyugdijmegtakarítást kereső fogyasztó hosszú távú védelme. Az európai szövetség, az Insurance Europe ugyanakkor arra is felhívja a figyelmet, hogy az SII folyamatban lévő revíziója során azt is szükséges megnézni, hogy a mostani elvárások hogyan viszonyulnak azokhoz a kockázatokhoz, melyeknek a biztosítók ténylegesen ki vannak téve. A hosszú távú kötelezettségekhez kapcsolódó jelenlegi SII elvárások újragondolása segítheti a biztosítókat abban, hogy aktív szerepet játsszanak a PEPP projektben.

4. A hordozhatóság elvárásának müködnie kell a kis-és a nagyszereplók vonatkozásában egyaránt annak érdekében, hogy megmaradhasson a verseny egy integrált európai piacon is.

A más EU-tagországban élő 20-64 éves korú EU-állampolgárok száma, ha nem is drámai sebességgel, de folyamatosan nő. Ez az arány azonban még mindig meglehetősen alacsony (a korosztály kevesebb mint 4\%-a), az állampolgárságuktól eltérő tagországban élő nyugdíjasok száma pedig 1,4 millió fö. A jogalkotó ugyanakkor a PEPP kapcsán választ szeretne adni a belső mobilitásból fakadó kihívásokra is. A rendelettervezet ennek megfelelően elvárja, hogy a szolgáltatók biztosítsák a hordozhatóságot arra az esetre, ha a befektető az EU-n belül tartósan országot vált. Ez lényegében azt az elvárást jelenti, hogy a terméknek tudnia kell kezelni valamennyi EU-tagország nyugdíjtermékekre vonatkozó szabályozását, beleértve az adókedvezményeket is.

A jogalkotó első megközelítésben ezt különböző zsebekkel képzeli el, melyek az ügyfél kérésére akár összevonhatók is lennének. A tervezetben szereplő megoldás (országonként egy „Zseb”) azonban ebben a formában túl komplex, mivel a PEPP szolgáltatónak számos kihívással kell megküzdenie (eltérő nyelvek, jogrendszerek, adókörnyezet). Azon kívül, hogy az elvárás jelentősen megnöveli a PEPP termékek költségét, könnyen oda vezethet, hogy csak a nagy cégek lesznek képesek PEPP terméket kínálni, ami szükségszerűen csökkenti a versenyt

Az Insurance Europe javaslata ebben a kérdésben is a rugalmasabb megközelítés. A PEPP szolgáltatónak legyen módja eldönteni, hogy mely országokra vonatkozó megoldásokat (nemzeti zsebeket) kínál. Abban az esetben, ha mégis felmerül a későbbiekben a kínálatban nem szereplő országra váltás igénye, a megtakarító számára a szolgáltatóváltás lehetőségét biztosítani kell. Mivel az Európán belüli mobilitás egyelőre még korlátos, indokolatlan lenne rétegigények miatt generálisan megdrágítani a PEPP terméket.
5. A tájékoztatási kötelezettségeket a termékspecifikumokhoz kell szabni.

A rendelettervezet a tájékoztatási kötelezettségek vonatkozásában a már alkalmazásban lévő KID (Key Information Document) dokumentumból indul ki, melyet az európai biztosítási piacok 2018 óta használnak. ${ }^{15}$ Ezt a dokumentumot egészítik ki további PEPP-specifikus elvárásokkal. Az Insurance Europe szerint alaposabb megfontolást igényel, hogy a KID mennyiben jelenthet kiindulópontot a PEPP termékekhez.

- $\quad$ A jelenleg javasolt PEPP KID struktúra nem az egyéni nyugdíjtermékek bemutatására szabott, hanem kifejezetten befektetési termékek számára készült, jellemzően rövidebb távú időhorizonttal. Ennek megfelelően még nem is tartoznak a PRIIPS rendelet hatálya alá a tagállamok által nyugdijtermék ként definiált konstrukciók. ${ }^{16}$

- $\quad$ Kérdés az is, hogy a PEPP KID séma hogyan tükrözi majd azokat a tagországi specifikumokat, melyek egy nyugdíjtermékhez kapcsolódhatnak (eltérő adókörnyezet, nyugdíjba vonulási életkor, alkalmazandó jog).

- A javasolt séma úgyszintén nem veszi figyelembe a lehetséges szolgáltatók széles körét. Az, hogy a PEPP termékek szolgáltatói egységesen megkapják az EU minőségi pecsétjét, a fogyasztót abba az illúzióba ringathatja, hogy minden PEPP termék esetében azonos védelmet kap, holott ez nem így van, mivel a védelem foka a terméket kínáló szolgáltatótól függ. Az Insurance Europe álláspontja szerint a szerződéskötés előtti tájékoztatásnak egyértelmüen jeleznie kellene a fogyasztó számára fontos körülményeket. Ilyen az intézményi garancia (SII), a kockázati fedezet, annak jelzése, hogy a termék tartalmaz-e olyan szolgáltatást (járadékfizetés lehetősége), amely alkalmas az élettartam-kockázat kezelésére. Mindezt annak érdekében, hogy a fogyasztó valóban teljes képet kapjon a megvásárolni kívánt nyugdíjtermékről.

Az európai szövetség nem első alkalommal és nem csak a PEPP kapcsán hívja fel a figyelmet a már abszurditásig túlzó tájékoztatási kötelezettségekre, melyek az évek elörehaladásával folyamatosan nőnek. Miközben érthető a jogalkotó törekvése, hogy minden szükséges információ a fogyasztó rendelkezésére álljon egy befektetési döntés meghozatalakor, elsikkad a lényeg, hogy a hangsúly a jobb, nem pedig a több információn van. A túlzóan sok információ kontraproduktívnak bizonyul, mivel abból a fogyasztó a valóban lényeges elemeket sem tudja már értelmezni.

Ezt nagyjából maga az európai jogalkotó is belátta, amikor a KID megalkotásával arra tett kísérletet, hogy kiemelje a fontosnak tekintett információkat a tájékoztatási cunamiból. Ugyanakkor a KID-re egyelöre úgy kell tekintenünk, hogy az kísérleti szakaszban van, tehát még bizonyítania kell. A KID gyakorlati alkalmazásával kapcsolatos kritikák ugyanis egyre erősödnek párhuzamosan azzal, hogy ezt a dokumentumot 2020-tól már az alapkezelői szektornak is alkalmaznia kellene két év derogáció után. ${ }^{17}$

Az Insurance Europe összeszámolta a tájékoztatási kötelezettségek darabszámát, melyek a majdani PEPP terméket terhelik egy biztosítási verzió esetén, és arra az eredményre 
jutottak, amit a 2. ábra mutat. A rendelettervezet szerint elvárt PEPP KID dokumentumra pluszként jönnek azok a tájékoztatási elvárások, melyeket a biztosítási termék értékesítőinek egyéb jogszabályokból adódóan teljesíteniük kell.

2. sz. ábra: PEEP tájékoztatási elvárások biztosítási termék esetében, elektronikusértékesítéssel (zárójelben az egyes szabályozások által előírt közlendő információk száma)

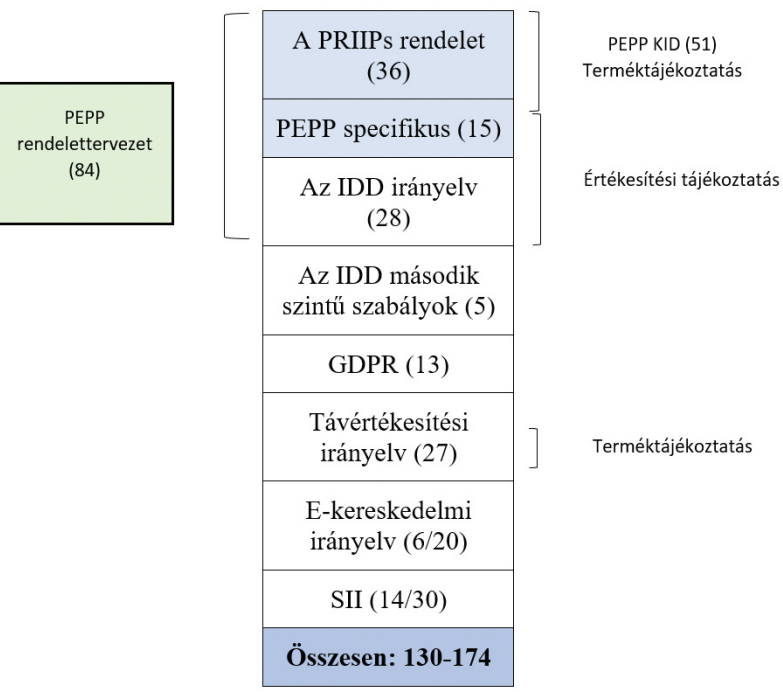

Forrás: Insurance Europe

A fenti statisztikát az Insurance Europe az elektronikus értékesítésre végezte el, mivel a PEPP rendelet a terméket erre a csatornára optimalizálja azzal, hogy föszabályként a tájékoztatásokat elektronikusan kell biztosítani. Ez az elem egyébként kifejezetten progresszív vonatkozása az új szabályozásnak, mivel egyéb esetekben (IDD, PRIIPs) a főszabály a tartós adathordozón történő tájékoztatás.

\section{Beszéljünk külön az adókedvezményröl!}

Nincs kétség afelöl, hogy azokban az országokban, ahol adókedvezményt élveznek a nyugdíjtermékek, ez jelentősen segíti a termékek szélesebb körben való elterjedését. Ezt támasztják alá a pozitív magyarországi tapasztalatok is.

Ennek megfelelően a Bizottság a PEPP rendelet előkészületi szakaszában ezt a kérdést is alaposan megvizsgálta, és három lehetőséget vett fontolóra.

1. A PEPP adókedvezménye az adott ország adókörnyezetéhez igazodna, azokra a termékekre járna, melyek megfelelnek a tagország nyugdíjtermékekkel szemben támasztott követelményeinek. Ez nem igényel EU-szintű jogalkotást, az EU-nak ott van feladata, hogy kikényszerítse az adókedvezmény biztosítását, ahol ez indokolt (lásd kötelezettségszegési eljárás). Ebben az esetben azonban a PEPP gyártóknak nagyobb mértékben kellene alkalmazkodniuk a helyi elvárásokhoz, ami korlátozza a hordozhatóságot. Probléma továbbá, hogy ha a PEPP a legkisebb mértékben is eltér a nemzeti elvárásoktól, már nem járna számára az adókedvezmény.

2. A PEPP adókedvezmény a tagország vonatkozó legkedvezőbb elbírásához igazodik. Ebben az esetben arra tenne a Bizottság javaslatot, hogy a tagországok adják meg a PEPP termékeknek azt az adókedvezményt, amelyet egyébként más nyugdíjtermékeknek biztosítanak még abban az esetben is, ha a PEPP nem minden elemében felel meg a vonatkozó tagországi elvárásnak. Ez a verzió igényli a tagországok önkéntes vállalását, hogy eleget tesznek a Bizottság felhívásának.

3. Speciális adórendszer bevezetésének a lehetősége is felmerült EU-szinten a PEPP termékekre, ami az összes közül a leghatékonyabb megoldás lenne, ugyanakkor ehhez a tagországok egyhangú jóváhagyása kellene. (Az adózás területe nem harmonizált jogterület, tehát a tagországok természetszerűen és jogszerüen alkalmaznak eltérő szabályokat.) Az egyéb szempontokon túlmenően - pl. hazai piac védelme - a tagországi beleegyezést az is akadályozhatja, hogy a nyugdíjtermékek adókörnyezete rendkívül különböző a tagországokban. A termék adókezelése három szakaszban kerül elő: a felhalmozás, a kifizetés és a hozam kapcsán, és valamennyi szakasz társulhat adóztatással, adómentességgel vagy adókedvezménnyel. A vizsgált nyugdíjtermékek ebből a szempontból is színes képet mutatnak, a lehetséges kombinációk mindegyikére van példa valamely

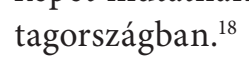

\section{Az adókedvezmény jelentősen segíti a termékek szélesebb} körben való elterjedését.

A Bizottság választása végül is a második megoldásra esett. Nem a jogszabálytervezetbe építve, de ahhoz szorosan kapcsolódva a Bizottság egy formalizált javaslatot fogalmazott meg az adózásra vonatkozóan. A testület javasolja, hogy a tagországok adják meg a PEPP termékeknek azt az adókedvezményt, amelyet egyébként más nyugdíjtermékeknek biztosítanak még abban az esetben is, ha az nem minden elemében felel meg a vonatkozó tagországi elvárásnak. Amennyiben különböző mértékű kedvezmények kapcsolódnak az egyes nyugdíjtermékekhez, akkor a javaslat az, hogy a legnagyobb kedvezményt élvezze a PEPP.

A hazai piac szempontjai ezen a téren jól ismertek. Az életbiztosítási piac növekedésének hajtómotorja a nyugdíjbiztosítás, nem teljesen függetlenül a 2014-ben bevezetett adókedvezménytől. Tavaly az új szerzések 21 százaléka már ebből a terméktípusból származott, és a pozitív trendek egyéb vonatkozásokban is megmutatkoztak a nyugdíjbiz- 
tosítások területén. Ebben a portfólióban stabillá vált a rendszeres díjas termékek aránya (97\%), nő az átlagos szerződéskötési tartam (19,2 év), ahogy az átlagos szerződési díj is nő (2017-ben már 206.004 Ft volt, szemben a 2016-os 184.662 Ft-tal). ${ }^{19}$ Egy európai minőségpecséttel ellátott nyugdíjtermék akár adókedvezmény nélkül is vonzó lehet a fogyasztók számára, de az adókedvezmény biztos, hogy attraktívabbá tenné.

\section{A PEPP rendelettervezet jelenlegi státusza}

Ahogy a bevezetőben jelzésre került, a PEPP tervezetet jelenleg a Tanács és a Parlament szakbizottságai tárgyalják. Ez utóbbi esetben három bizottság is részt vesz a munkában: az ECON (gazdasági), EMPL (szociális) és az IMCO (fogyasztóvédelmi). Mindegyik testületben születnek módosító javaslatok az induló szöveghez (az ECON bizottságban pl. 800 van kézben), de még nem tudjuk, hogy melyek kerülnek elfogadásra, vagy éppen esnek ki a rostán. A procedúra legvégén pedig majd össze kell fésülni a Parlament és a Tanács által jóváhagyott szöveget, ami nem lesz könnyü feladat.

Az induló szöveg tehát akár még jelentős mértékben is változhat, az a jogalkotói ambíció ugyanakkor változatlan, hogy a PEPP szövegét a lehető legkorábban, de mindenképpen még a 2019-es EP választások, illetve a Bizottság tisztújítása előtt véglegezzék. Ezt szolgálja az is, hogy a Tanácsban annak ellenére, hogy még nem született minden kérdésben egyetértés, júniusban elfogadtak egy kompromisszumos szöveget, ami lehetővé teszi, hogy a 2018. második féléves osztrák elnökség az egyeztető megbeszéléseket a Parlamenttel rögtön a nyári szünet után megkezdhesse. Ez nyilván felvethet bennünk olyan aggodalmakat, hogy a sietség nem megy-e majd a minőség rovására.

Az uniós jogalkotás az immár megszokott módon nem áll meg az első szintű rendelet megalkotásánál. Ennél a pontnál célszerű röviden utalni a többszintű EU-jogalkotás mostanra már állandónak tekinthető problémájára.

A többszintű szabályozási rendszert a 2009-es Lisszaboni Szerződés vezette be a pénzügyi szolgáltatók vonatkozásában. Korábban is volt hasonló (Lámfalussy kommitológiai eljárás). A jogalkotási technológia oka pedig az, hogy az első szintű szabályok (L1, irányelv) a téma technikai jellege miatt nem tudnak minden szükséges részletet tartalmazni, ezért azok általános szinten maradnak. Ezeket próbálják azután tovább pontosítani a szakmainak szánt második (L2, végrehajtási rendelet) és harmadik (L3, ajánlások) szintű szabályok. A fontos végrehajtási részleteket tartalmazó második szintű szabályok ugyanakkor rendszeresen késve, az alkalmazási határidőt csak röviddel megelőzve készülnek el, sőt, arra is van példa, hogy az alkalmazást követő 8. hónapban még mindig nem készült el egy részletkérdést szabályozó rendelet. ${ }^{20}$

A biztosítási szakma ezért általános érvénnyel azt javasolja, hogy ez a jogalkotási technika az ütemezés vonatkozásában kerüljön újragondolásra, és a szabályok alkalmazási határidejét a második szintű szabályok megjelenését követő egy évvel későbbi időpontban határozzák meg.

\section{Egy rövid kitérö}

Jelen cikk - a témából adódóan - az egyéni nyugdíjtermékekre koncentrál, mivel a mostani európai kezdeményezés célja az, hogy ennek a piacnak adjon lökést. Ugyanakkor a nyugdíjkörképhez szorosan hozzátartoznak a csoportos módozatok is, melyek legszélesebb körben elterjedt verziója a foglalkoztatói nyugdíj intézménye (IORP). Az egyes országoknál egészen más számokat találnánk az 1. sz. táblázat nyugdíj-megtakarításokra vonatkozó részénél, ha az IORP adatokat is megnéznénk. Az IORP elterjedtsége folyamatosan nőtt az elmúlt években. Mostanra az EU foglalkoztatottak 15 százaléka becsatlakozott, amely szám a valóságban még ennél is nagyobb, mivel a brit és a francia létszámadat nem elérhetö, miközben az IORP eszközök 42 százaléka brit szolgáltatóknál van. (A második kiemelten nagy szereplő a holland piac, az összes IORP vagyon 34\%-ával. $)^{21}$

Miért érdekes ez? Mostanra szélesebb körben is megismerhetővé váltak a viselkedési közgazdaságtan eredményei, mely tudományág az egyéni megtakarítások vonatkozásában is érdekes szempontokat hozott be a gondolkodásba. Egy hosszú távú, jellemzően illikvid termék melletti elköteleződést - a nyugdíjbiztosítás ilyen - kognitív és érzelmi korlátok akadályoznak. Egy átlagos ember a nyugdíjcélú megtakarítást mindig inkább csak holnap szeretné elkezdeni, akárcsak a fogyókúrát, mert nehezen áldozzuk fel a rövid távú fogyasztást a hosszú távú előnyökért.

Nem véletlen, hogy a biztosítók bizonyultak a legsikeresebbnek az egyéni nyugdíjtermékek értékesítésében, mivel a személyes értékesítés tudja oldani ezeket a kognitív és érzelmi korlátokat. Ugyanakkor azt is látjuk, hogy ahol meg tudott gyökeresedni az IORP, ott komoly nyugdíj-megtakarítások halmozódnak fel, mivel a munkahelyre történő belépéssel lényegében automatikusnak tekinthető a csatlakozás a rendszerhez, az onnan való kiválás igényel személyes döntést. Ez a megoldás a viselkedési közgazdaságtannak arra az igazságára épít, hogy az átlagos ember többnyire az alapértelmezett megoldást választja, amikor nem kell csinálni semmit („doing nothing default option”).22 Ilyen módon tehát úgy növelhetők az egyéni megtakarítások, hogy az nem igényel egyéni szintű döntést.

\section{Összegzés}

Összefoglalva az eddigieket leszögezhető, hogy a nyugdijkérdés aktuális és fontos, az EU- és tagállami szinten egyaránt foglalkoztatja a jogalkotókat. Minden lehetséges megoldást mérlegelni kell, tekintettel arra is, hogy folyamatosan változnak a foglalkoztatási viszonyok a korábban atipikusnak tekinthető megoldások elterjedésével (lásd önfoglalkoztatás). A most bemutatott PEPP szabályozás egy ilyen kísérletnek tekinthető, mely egy olyan egyéni nyugdíjterméket szeretne meghonosítani az EU-ban, amely szélesebb körben is vonzóvá tud válni, és a költséghatékonyság okán érdemben tudja bővíteni a nemzeti piacokon már most is meglévő egyéni nyugdíjtermékek választékát. 


\section{HIVATKOZÁSOK}

Ju/info/business-economy-euro/banking-and-finance/insurance-and-pensions/personal-pension-products_en

európai forrás (Id. 4.sz. lábjegyzet) EU28-ról beszél, az összehasonlitásnál kiindulópontnak tekintve az 1960. évi A foká, holott az EU csak 1993. november 1-jén jött létre, a hajdani EGK pedig 1957-ben mindossze 6 taggal alakult. ostani tagország vonatkozásában.

elérése lenne szükség.

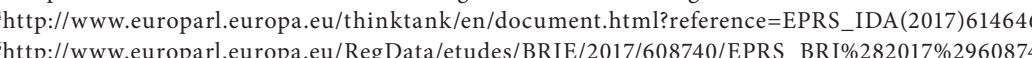

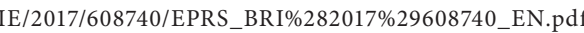

PRIPPs KID dokumentumot jelenleg még nem kötelező alkalmazni a tagországok által nyugdijtermékként meghatáAzott termekekre.

port_-_Online_Version.pd

${ }^{8}$ https://ec.europa.eu/info/business-economy-euro/growth-and-investment/capital-markets-union

A forràs (Commission impact assesment on PEPP) a nyugdijalapok fogalmához az OECD definíció szerinti intézményeket sorolja, lásd: https://stats.oecd.org/glossary/detail.asp?ID=5337

' $z$ IORP a foglalkoztatói nyugdijellatást szolgáló intézményeket jelzi, mely intézmény Európában szélesebb körben is elterjed (lásd a cikben Kesobb). Magyarorszagon ezt az intezményt a 2007. évi CXVII vezette be, de ezek piaci szerepe jelenleg még elhanyagolhato. Az aubran kulons szerepelnek a biztosito es nyugdijbiztositó intézmények. Ez utóbbiak reszaranya nem szignifikáns, nem eri el az 1\%-ot. A kulonbsegtetelnek adatgyujtesi okai lehetnek, egyes tagországokban la illetve összesités korlátait az EIOPA anyag III. melléklete tartalmazza az alábbi linken.

ttps://eiopa europa eu/Publications/Consultations/EIOPA\%275\%20advice\%20on\%20the\%20development\%20 of\%20an $\% 20$ EU\%20single\%20market\%20for\%20personal\%20pension\%20products.pdf

${ }^{12} \mathrm{Az}$ ebben a fejezetben bemutatott érvek és szempontok az európai biztosítók szövetsége, az Insurance Europe hivatalos álláspontját tükrözik: https://insuranceeurope.eu/pan-european-pension-product-pepp-key-messages

Ennél a kifizetési formánál az ügyfél dönti el, hogy milyen ütemezésben, illetve bontásban hívja le a rendelkezésre álló összeget, mely a tőkegyüjtési szakaszban felhalmozódott.

"nnek a kockazatnak van biztositásmatematikai vetülete is, melyre a longevity kockázat kifejezést használják. Ez járadékban történỏ szolgáltatás esetén a járadék folyósitójának azt a kockázatát jelenti, hogy a járadékra jogosultak átlagosan hosszabb ideig élnek, mint amilyen âtlaggal a kifizetỏ kalkulált.

เhttp://www.mabisz.hu/images/stories/docs/biztositas-es-kockazat/4_4/biztositas-es-kockazat-4-evf-4-szam-2-cikk.pdf Nem tartoznak a PRIIPs rendelet - vagyis a KID dokumentum eloällitási kötelezettsége - alá azok a nyugdíjbiztositási termékek, amelyek a nemzeti jog alapján elsődleges céljukat tekintve a befektetôs számára nyugdijjövedelmet biztosító és a befektetöt bizonyos ellatáasokra feljogositto termeknek ismernek el. Habar Magyarországon a nyugdijbiztositásokhoz - bizonyos, az SZJA. törvênyben rơgzitett feltételek teljesullése esetén - adokedvezmèny kapcsolódik, ez önmagában KID dokumentumot amely az értékesítés előtti tájékoztatás szolgálja. Ez a hazai alkalmaź́s ugyanakkor nem jelenti

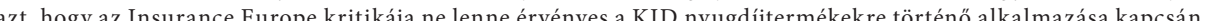
the ${ }^{18} \mathrm{~h} t \mathrm{ps}$ ///ec we

${ }^{19} \mathrm{MNB}$ adatok, Portfolio.hu Konferencia, 2018. március 8.

${ }^{20} \mathrm{~A}$ PRIIPs rendelet 8 (4) pontja szerint a KID-ben fel kell tüntetni, ha egy befektetési eszköz társadalmilag hasznos célokat szolgál (környezetvédelem stb.). A társadalmilag hasznosnak tekinthető befektetések kritériumait egy második szintủ végrehajtási rendeletnek kellene rögzítenie, mely jogszabály a mai napig nem született meg, miközben a pénzügyi szolgáltatók már 2018. január 1. óta kötelesek eloóllitani az ügyfél-tájékoztatást szolgáló KID dokumentumot.

${ }^{21}$ https://eiopa.europa.eu/Publications/Reports/EIOPA-BOS-18-013-2017\%20Market\%20Development\%20Report.pdf

2hhttps://www.ted.com/talks/shlomo_benartzi_saving_more_tomorrow

\section{IRODALOMJEGYZÉK}

Better Finance: Pension Savings, The Real Return, 2017 Edition

http://betterfinance.eu/fileadmin/user_upload/documents/Research_Reports/en/Pension_Report_2017__Full_Report___Online_Version.pdf
letöltés: 2018.07.12

IOPA: 2017 Market development

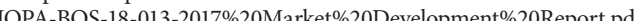

letöltés: 2018.07.12.

EIOPA EIOPA's advice on the development of an EU Single Market for personal pension products

https://eiopa.europa.eu/Publications/Consultations/EIOPA\%27s\%20advice\%20on\%20the\%20development\%20 of $\% 20$ an $\% 20 \mathrm{EU} \% 20$

ingle\% 20 market $\% 20$ for 202 pers

(1) KID's shortcomings, 2018

https://www.efama.org
letöltés: 2018.07 .12

Európai Bizottság benyúitott PEPP rendelet tervezet

https://ec.europa.eu/info/publications/170629-personal-pension-products_e

letoltés: 2018.07.12.

https://ec.europa.eu/info/business-economy-euro/growth-and-investment/capital-markets-union

letöltés: 2018.07.12

Assesment on PEPP

http://www.europarl.europa.eu/RegData/etudes/BRIE/2017/608740/EPRS_BRI\%282017\%29608740_EN.pd
letöltés: 2018.07.12.

Haraszti Zsófia - Mátyás Mikós Dániel - Turi Petra: PRIIPs rendelet, Biztositás és Kockázat IV. évfolyam 4. szám

http://www.mabisz.hu/images/stories/docs/biztositas-es-kockazat/4 4/biztositas-es-kockazat-4-evf-4-szam-2-cikk.pd

http://dx.doi.org/1018530/BK.2017.4.14

letöltés: 2018.07.12.

Key Messages on PEPP, 2018

https://in

Insurance Europe: A Blueprint for Pensions, 2017 February

https://insuranceeurope.eu/sites/default/files/attachments/A\%20Blueprint\%20for\%20Pensions.pd

Risto Nieminen - David Eatock (Euroepan Parliamentary Research Service): In-depth analysis on PEPP

http://www.europarl 